\title{
やり投げ競技を対象とした運動観察におけるスーパースロー 映像の有効性に関する基礎的検討
}

\author{
Effects of Super Slow Movie on Motion Observation of Javelin Throw
}

\author{
伊 勢 只 義 \\ Tadayoshi Ise ${ }^{\dagger}$, Takeaki Shionome ${ }^{\dagger \dagger}$ and Shinichi Watabe ${ }^{\dagger \dagger}$
}

\begin{abstract}
Recently, video footage has been used for motion observation of primary players for sports instruction. In this paper, we analyze motion observation of an expert javelin thrower at several frame rates of attempt movie. We obtained an interview with an expert javelin instructor to investigate the effectiveness of high speed movies on motion observation with frame rates of 30, 60, 120, and $240 \mathrm{fps}$. As a result, (1) playback times, (2) pause times, (3) fast-forward or rewind times, and (4) playback order were measured. In addition, 57 of the meaningful units for instruction were obtained from the interview analysis. The results also show that the high speed movie is effective for figuring out a player's conscious of bodymotion and setting an agenda to adjust motion in dynamic postures for motor learning. The differences of the tendency of motion observation between each frame rate were also discussed.
\end{abstract}

キーワード : やり投げ, 競技指導, スーパースロー映像, 高速度カメラ, 運動観察, 動作意識

\section{1. ま え がき}

スポーツにおいて，運動スキルの獲得を目的とした運動 学習では, 学習者本人が見本となる動作を観察し, 特徵を 押さえて練習をすることが効果的であるとされている ${ }^{11)}$. 運動指導を考える場合, 指導者は学習者が注意を向けるべ き動作を正確に把握し, 学習者に動作の修正のポイントを 指摘しなければならない。一方, 運動スキルを指導する場 合の問題として，客観的に観察される行為と運動実施者本 人が意図して行う動作意識*には異なる点が多いことも指摘 されている ${ }^{3)}$. 動作を学習する場合, この動作意識に意困 的に注意を向けることが求められる ${ }^{11)}$.また，優れた運動 競技者は, 動作中に感知する動作意識と観察される動きと しての動作結果を正確に対応付けながら動作の調整を行っ ている ${ }^{4)}$. すなわち, 指導者は学習者に運動指導を行なう 際, 学習者の動作の修正のポイントを学習者の動作意識と

2012 年 1 月 27 日受付, 2012 年 4 月 3 日再受付, 2012 年 4 月 24 日採録 †東北大学 大学院教育情報学教育部, 022-795-3119

( 于 980-8576 宮城県仙台市青葉区川内 27-1)

††東北大学 大学院教育情報学研究部, 022-795-3117 ( 个 980-8576 宮城県仙台市青葉区川内 27-1)

† Graduate School of Educational Informatics Education Division, Tohoku University

(27-1, Kawauchi, Aoba-ku, Sendai, Miyagi 980-8576, Japan)

$\dagger \dagger$ Graduate School of Educational Informatics Research Division, Tohoku University

(27-1, Kawauchi, Aoba-ku, Sendai, Miyagi 980-8576, Japan) * 動作中に本人が主体的に感じ取る主導的な感じ，あるいは体験 7)
客観的事実を正確に対応させられる客観的視点を持つこと が要求される。

近年, 学習者の動作の観察の際に, ビデオ映像が活用さ れている ${ }^{6) 910)}$. ビデオ映像を運動指導に活用することの 重要性について, Duane ${ }^{2)}$ は「肉眼では観察できない運動 の高速な事象をとらえることができる」と述べている.こ のことからも，運動指導場面において，ビデオ映像の活用 は学習者の運動スキル獲得の一助になると考えられる. 加 えて, 高速度カメラを使用し, 競技者の動作の特性をより 詳細にとらえようとする試みも行われている ${ }^{5) 8)}$. しかし ながら, スーパースロー映像がビデオ映像よりも学習者の 動作の観察の際に有効とされていても，優れた指導者が実 際のビデオ映像，およびスーパースロー映像をどのように 観察し, どのような観点からスポーツ競技者の動作の修正 のポイントを把握しているのかについての検討は充分では ない.

本稿では，エキスパートやり投げ競技者を対象として，実 際のビデオ映像, およびフレームレートの異なるスーパー スロー映像を指導者の視点から観察してもらい, 修正ポイ ントの把握をどのように行っているかを実験的に検討して いる，すなわち，運動指導におけるスーパースロー映像の 観察行動を分析することで, その有効性を明らかにするこ とを目的とする. 


\section{2. 実 験 方 法}

やり投げ競技指導の観点から，フレームレートの異なる やり投げ試技映像（30，60，120，240fps）を対象として， 試技の観察への有効性を検討するためインタビューを行う.

\section{1 評価映像}

ここでは評価映像の作成, 提示方法について説明する.

まず，1名のやり投げ競技者（20 代，男性，右投げ，競 技歴 7 年, 自己ベスト記録 77 m 76） のやり投げ試技の様 子を左側面からディジタルカメラ（Fujifilm HS-10）を使 用し，240fps のハイスピードモード（空間解像度 : $443 \times$ 332 pixel）で撮影した. 試技は 6 回撮影され, そのうち最 も記録の良かったものを評価映像として使用することとし た。なお，試技映像は助走，クロスステップ，投げ，フォ ロースルーを含み，実時間として 11 秒程度の長さである.

次に，撮影した映像を Premiere Pro CS3 (Adobe 社)を 用いて, クリップ速度・デュレーションの調整により, 120 , 60, 30fps に加工し, MP4 形式 (H.264, 29.97fps, $720 \times$ 480pixel, レベル $3.2, \mathrm{VBR} \cdot 2$ パスエンコード) で書き出 した.

評価映像は，ノート PC (hp Pavilion dv6, 解像度 1024 $\times$ 768pixel, Windows7, core i5 プロセッサ) にSimplayerWMPX3beta3 (Finalsoft 製) を用いて提示する。 その 際, 映像提示ウインドウのサイズ・位置を調整し, 画面上 に 4 種のフレームレートの試技映像を配置している。 ウィ ンドウサイズ調整後の映像の空間解像度は $428 \times 318$ pixel である（図 1）。

\section{2 被験者}

実験には，モデルとは異なる 1 名のエキスパートやり投 げ競技者（20 代，男性）に参加してもらった. プロファイ ルは表 1 のとおりである。プロファイルから，競技歴，競 技実績, 指導歴ともにエキスパートやり投げ競技者として 認められる被験者であるといえる.

\section{3 評価手順}

被験者には，4 種のフレームレートのやり投げ試技映像 を自由に再生してもらい, その映像観察行動とやり投げ競 技指導につながる発話を記録している. 被験者が操作して いるノート PC の画面をディジタルビデオカメラ（SONY

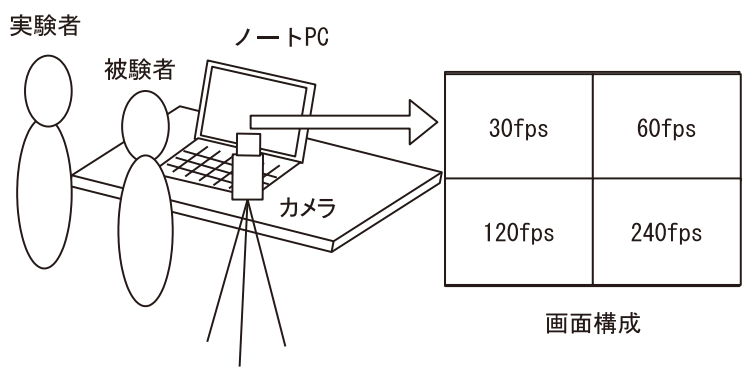

図 1 実験状況 Situation of experiment.
HDR-SR11）で撮影し，発話内容を被験者の了解のもと IC レコーダー (OLYMPUS VoiceTrek V-61)，およびビデ オカメラのワイヤレスマイク（SONY ECM-HW2） で記 録している. 実験状況の概要, および映像提示の際の画面 構成を図 1 に示す。

被験者には，あらかじめ PC の操作方法（動画の再生，停 止，巻き戻し，早送り等）について説明し，「動画を見なが ら指導者としてこの競技者の記録を向上させるための動作 のポイントを挙げてください. ポイントはいくつ挙げてい ただいてもかまいません」のように教示した，なお，被験 者の発話に対しては，被験者の発言を誘導しないように実 験者の評価を控えた非指示的なスタイルの質問を行うと同 時に, 被験者自身が語った言葉を用いて反応する*ことで, 実験者の影響を少なくするよう考慮している.

\section{3. 結 果}

ここでは，記録した映像データ，および発話データの分 析結果について示す. 得られた約 70 分の映像・音声データ から, (1) 各フレームレートの映像再生回数, および再生時 間, (2) 一時停止回数, (3) スキップ回数（早送り,または 巻き戻し回数）を計測した（表 2）。また，各フレームレー 卜の映像再生順序を図 2 に示す。さらに，発話データから 文字おこしの結果，約 18000 字のトランスクリプト・デー タが得られた。この中から，やり投げ競技指導に関する一 つ以上の概念や見解を含む 57 の意味内容要素が得られた （表 3)。また，表 4 に発話の一部を抜粋し，発話の夕イミ ングを図 2 に括弧付き数字で示す.

\begin{tabular}{|c|c|}
\hline 競技歴 & 12 年 \\
\hline 競技実績 & $\begin{array}{l}2007 \text { 年, アジア陸上競技選手権大会で } 5 \text { 位入賞, } \\
2010 ・ 2011 \text { 年, 全日本実業団選手権で優勝. } \\
\text { 自己ベスト記録は } 78 \mathrm{~m} 87 \text { (日本記録は } 87 \mathrm{~m} 60 \text {, } \\
\text { 世界記録は } 94 \mathrm{~m} 48 ） .\end{array}$ \\
\hline 指導歴 & $\begin{array}{l}\text { 陸上競技専門誌 }{ }^{1)} \text { にやり投げ競技トレーニングの } \\
\text { 解説記事を寄稿. } \\
\text { 所属陸上競技部の選手兼コーチとして活動中. }\end{array}$ \\
\hline
\end{tabular}

表 2 各フレームレートの映像再生状況

Replaying statistics for each frame rate.

\begin{tabular}{c|r|r|r|r}
\hline \hline & $30 \mathrm{fps}$ & $60 \mathrm{fps}$ & $120 \mathrm{fps}$ & $240 \mathrm{fps}$ \\
\hline 再生回数 & 21 & 22 & 11 & 52 \\
平均時間 & $5.68 \mathrm{sec}$ & $5.19 \mathrm{sec}$ & $7.6 \mathrm{sec}$ & $7.98 \mathrm{sec}$ \\
合計時間 & $119.35 \mathrm{sec}$ & $113.48 \mathrm{sec}$ & $80.66 \mathrm{sec}$ & $413.78 \mathrm{sec}$ \\
一時停止回数 & 15 & 8 & 5 & 29 \\
スキップ回数 & 6 & 14 & 6 & 23 \\
\hline
\end{tabular}

表 3 抽出された意味内容要素数 Obtained meaningful units.

\begin{tabular}{l|r|r|r|r|r}
\hline \hline & $30 f p s$ & $60 f p s$ & $120 f p s$ & $240 f p s$ & 合計 \\
\hline 意味内容要素数 & 12 & 6 & 3 & 36 & 57 \\
\hline
\end{tabular}

*例えば，被験者の「‥ヒザがドンとつぶれていてどんどん力が逃げてし まう」という発話に対して「つぶれないとはどのくらいのことを言うの ですか?」のように受け答えする. 
表 2,3 から, 各フレームレートにおける映像再生回数・ 再生時間, および意味内容要素数は 240fps の映像再生時 に最も多くなっており, 次に意味内容要素数が多かったの は 30fps の映像再生時となっていることがわかる。また, 120fps の映像では再生時間, 再生回数, 意味内容要素数が 最も少なくなっていることがわかる.

図 2 から，実際の動きの速度と同等の $30 \mathrm{fps}$ の映像から 観察し, 順番に高フレームレートの映像を再生し, 240fps の映像を長く再生していることがわかる，また，後半では 30fps の映像と 240fps の映像とを交互に観察していること もグラフから見て取れる.

次に，表 4 の発話と図 2 に示した発話タイミングとの関 連について述べる. まず, 被験者は $30 \mathrm{fps}$ の動画再生時に 修正のポイントとして, やりの保持について 表 4-(1) のよ うに述べている. 寸なわち, 被験者は映像を通して確認で きる客観的な事実から修正のポイントを述べており，選手 の動作を一連の流れの中でとらえようとしていたことがわ かる.

一方，被験者は 240fps の映像再生時にやりを投げる瞬間 の下半身の修正ポイントを動作意識に触れながら表 4- $(2)$ のように述べている.さらに, 被験者は右足の接地から左 足（ブロック脚）の接地の仕方の修正について表 4-(3)の ようにも述べている。

このように被験者は，240fps の再生時において 30fps の 再生時とは対照的に動作の修正のポイントを選手と被験者 自身の動作意識を照らし合わせながら動作の課題を捉えて いることがわかる. 加えて, 被験者は 240fps の映像再生 時に動作の観察における修正のポイントの把握について表 4-(4)のようにも述べている.

さらに，被験者は 240fps の映像再生後に，30fps の映像 を再生しながら, 動作の観察において表 4-(5)のように, 実 際のスピードの映像の重要性について言及している.

以上の発話から, 映像の再生順序に関して $240 \mathrm{fps}$ の映像 から多くの動作の修正ポイントを把握し，そのポイントを 実際のスピードの映像（30fps）と対応付けていくことがわ かった。

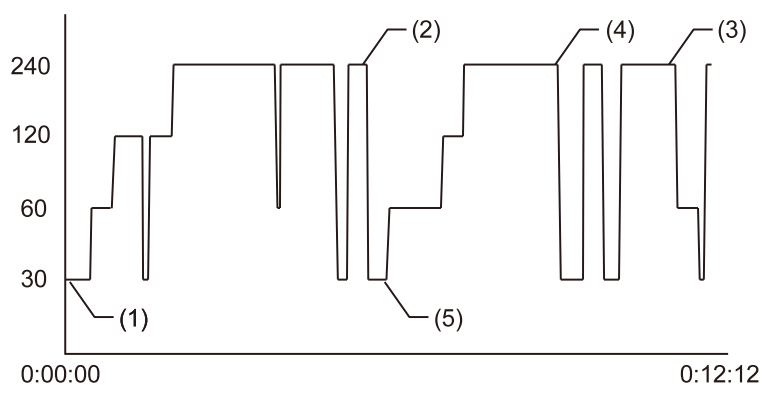

図 2 全映像再生時間中の各フレームレートの映像再生順序 Replaying order of each frame rate.

\section{4. 考 察}

ここでは，スーパースロー映像によるやり投げ競技の観 察行動，および発話の分析結果から，スーパースロー映像 の競技指導への有効性について考察する.

本実験において，エキスパートやり投げ競技者のフレー ムレートの異なるやり投げ試技映像の観察行動は，240fps の映像による動作の修正ポイントの意味内容要素が最も多 いことがわかった（表 3）。このことは，試技の動作を詳 細，かつ客観的に把握することで，より多くの動作の修正 ポイントを発見できることを示していると考えられる。ま た，30fps の映像再生時には見られなかったが，240fpsの 映像再生時には，修正のポイントに関寸る発話の視点が選 手の動作意識に向けられていた。運動学習において，学習 者は自身の動作意識に注意を向けながら，動作の修正を行

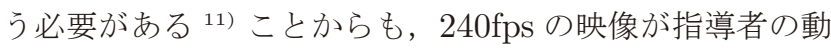
作の修正のポイントの正確な把握につながったことは，高 フレームレート映像の競技指導への有用性を示すものと考 えられる。

次に, $30 \mathrm{fps}$ の映像再生時には, 動作の修正ポイントを実 際のスピードの映像を通して，対応付けていくことによっ て，動的姿勢（連続的な一連の動作）の中で修正ポイント の把握を行っている傾向が見られた。運動スキルを獲得す るためには，学習者は修正のポイントを動作意識に向ける だけではなく，連続的な動的姿勢の中で課題達成を行うこ

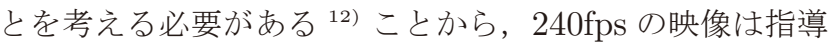
者が選手の動き（一連の試技の流れ）の中での動作の修正 ポイントを把握する一助になったと考えられる.

表 2 の映像再生状況からは, 30fps の映像では一時停止回 数が多くなっていることがわかり，実際のスピードでは修 正ポイントの発見が難しいことが示唆される。また， $60 \mathrm{fps,}$

表 4 発話の抜粋

Excerpted statements.

\begin{tabular}{|c|c|}
\hline (1) & $\begin{array}{l}\text { まず助走の入りです. 入りから投げ終わるまでの一連の } \\
\text { 動作で, やりを最初に構える向きが自分の肩のラインと } \\
\text { 骨盤の面に対して上を向き過ぎています. } \\
\text { 最初の助走の入りの所で, 単純にやりの穂先としっぽを } \\
\text { 自分の手の平, 肩, 腰と同じ平行に構えるべきです. }\end{array}$ \\
\hline (2) & $\begin{array}{l}\text { (投げる瞬間に) 右足は離れていくけど接地してるときは, } \\
\text { 地面にしっかり押さえておきながら，その延長上に根を } \\
\text { 張るイメージです. 左足もしっかり根を張って吸い付いて } \\
\text { 力が腰の方に伝わってくるというか. } \\
\text { そういう状態が最高の状態です. }\end{array}$ \\
\hline (3) & $\begin{array}{l}\text { ここ (左足を付く時の) 一瞬の間がいつもの感覚とズレて } \\
\text { しまっているというか. } \\
\text { 良い時はここの間がコンマ何秒早く腰の移動ができている } \\
\text { と思うので. 良い時だとこのくらいの時に接地してる感覚 } \\
\text { なのかもしれません. }\end{array}$ \\
\hline (4) & $\begin{array}{l}\text { 右ひざが割れてしまう動きとか下半身の動きは } 240 \text { の } \\
\text { スピードで見ないとわからない時もあると思います. }\end{array}$ \\
\hline (5) & $\begin{array}{l}\text { ただ，30fps の映像で大事なところっていうのはやっぱり } \\
\text { スピード感です. スーパースローで再生スピードが落ちると } \\
\text { やりが飛んでいく速度もわからなくなるのでそれは弊害に } \\
\text { なってしまいます. }\end{array}$ \\
\hline
\end{tabular}


120fps の映像の場合には, スキップ回数が一時停止回数を 上回っていることから, 細かな動作の場面を観察するより も, ゆっくりとした動きの流れを観察することに適してい ると考えられる.さらに, $240 \mathrm{fps}$ では一時停止回数, スキッ プ回数ともに最も多くなっており，個別の動作の場面（や りの保持の角度や，接地時の脚の角度など）の観察に適し ていると考えられる. すなわち, 異なるフレームレートの 映像を観察するときには，異なった視点で修正ポイントを 発見しようとしていることが示唆されている.

以上をまとめると, (1) 再生時間, 再生回数, および意 味内容要素数は 240fps の映像再生時が最も多く, 競技指 導の観点からスーパースロー映像の重要性が明らかとなり, (2)30fps の映像観察時には実際の動きのスピードを想定し た発話が得られ，(3)30fps では実際の動作スピードでの指 導， $60 \mathrm{fps}$ では動的姿勢の把握を維持した指導，240fps で は動作の場面を細かくとらえた指導の視点が得られること が明らかとなった. 寸なわち, 実際の動作スピードの映像と 高フレームレートの映像を併用して試技の様子を観察する ことで, やり投げ競技の指導に対する視点の多様な変化を 促し，より多くの動作の修正ポイントを指摘することが可 能になることが示唆された. また, やり投げは複数の運動局 面（助走，クロスステップ，投げ）で構成されるため, 各局 面で観察に適したフレームレートが異なることや，より高 いフレームレートが必要となることも示唆される.さらに, やり投げ競技だけではなく, 他の競技においてもスーパース ロー映像を活用することで, 動的姿勢の中での修正ポイント の発見だけでなく, 競技者の動作意識にも目を向けた指導が 可能になると考えられる. 例えば, 短距離走の動作の詳細な 把握に必要なシャッタスピードは $1 / 200 〜$ (200fps), 野球 の投動作の場合は 1/500〜 (500fps), サッカーも 1/500〜 (500fps) といわれている ${ }^{2)}$. すなわち, やり投げは短距離 走と同程度のスピードの助走と投動作からなる競技であり， 本検討での知見は他の競技の運動観察においても有用であ ると考えられる。

\section{5. むす び}

本稿では，エキスパートやり投げ競技者によるスーパー スロー映像を用いた競技指導について, 実験的に検討した. 4 種のフレームレート $(30,60 ， 120 ， 240 f p s ）$ のり投げ 試技映像の観察行動を分析した結果から, 動作の修正に対 する指導者の視点を動作意識に向けさせること, および動 的姿勢における動作の課題設定に対する有効性が明らかと なった.

今後の課題としては, 今回得られた指導に関する発話を 映像とともに選手にフィードバックし，スキル向上に寄与 するかどうかの検討があげられる。また，スーパースロー 映像の初級者の競技の振り返りへの適用や, 本検討との比 較があげられる.さらに，競技会等の現場で試技の様子を 観察・振り返りを行うことで, 即時的に投げ方の修正や記
録の向上が可能であるかの検討が必要であると考える.

本研究を遂行するにあたって，七十七銀行陸上競技部・ 荒井謙選手，および仙台大学陸上競技部・佐藤寛大選手の 両名にご協力いただきました。ここに記し，謝意を表する とともに，今後のご活躍を祈念いたします。

\section{〔文献〕}

1）荒井謙 : “トップ選手に学ぼう!!一流のトレーニングメソッド”，月刊陸 上競技， 45，12，pp.180-183，講談社（2011）

2) Duane V.K., Craig S.M., 阿江通良監訳 : “体育・スポーツ指導のた めの動きの質的分析入門”，ナップ (2007)

3）麓信義 : “新しいスポーツ心理学入門”, 春秋社 (2000)

4）伊勢只義，塩野目剛亮：“エキスパートやり投げ競技者の動作意識に関 する基礎的検討”, ヒューマンインタフェースシンポジウム 2011 対話 発表, 2561P, pp.855-856 (2011)

5）岩瀬祐人, 村上正秀, 平井伸幸, 瀬尾和哉, 仰木裕嗣：“高速度ビデオ カメラの画像解析によるスキージャンプの飛型と飛距離の相関 (ウィン タースポーツ)", 日本機械学会, ジョイント・シンポジウム講演論文 集, スポーツ工学シンポジウム, ヒューマン・ダイナミックス. symposium on sports engineering:symposium on human dynamics, B-31, 391-396 (2009)

6）金子元彦：“バドミントンの打動作における主観的努力度と客観的達成 度の対応関係一主観的努力度に指示語を用いて-”, 順天堂医療短期大学 紀要, 11, pp.51-62 (2000)

7）成瀬悟策：“動作訓練の理論”，誠信書房（1985）

8) 高松学, 飯塚大輔, 中村康雄, 中村真理, 林豊彦, 信原克哉: “高速度ビ デオカメラシステムを用いた身体動作の無拘束測定”, 信学技報, MBE, ME とバイオサイバネティックス, 104-319, pp.21-24 (2004)

9）筀俊市郎，斎藤隆文，田中秀幸：“スポーツ指導のためのビデオ映像処 理”, 情報処理学会研究報告, グラフィクスと CAD 研究会報告, 110-7, pp.37-42 (2003)

10）佐藤進，出村慎一，北林保，野口雄慶：“指導現場における競泳のスタ一 卜技能評価法の提案”, 水泳水中運動科学, 7, pp.29-33（2004）

11）杉原隆：“運動指導の心理学-運動学習とモチベーションからの接近一”, 大修館書店 (2003)

12）山本裕二著, 杉原隆編：“スポーツ心理学の世界”, 福村出版（2000）

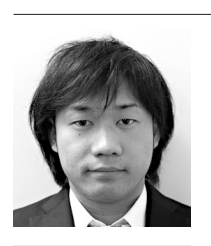

伊爇 只義 2009 年, 宮城教育大学・保健体育専攻 卒業. 2011 年，東北大学大学院教育情報学教育部・教育 情報学専攻修了. 同年, 同大学院博士後期課程進学. 修 士 (教育情報学)。スポーツ科学領域におけるテクノロ ジ一活用に関する研究に従事.

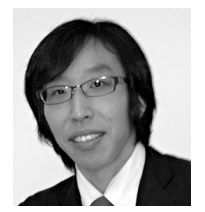

しお方野目剛亮 2002 年, 宇都宮大学工学部卒業. 2007 年, 宇都宮大学工学研究科 生産 - 情報工学専攻修了. 同 年, 筑波技術大学産業技術学部特任助教. 2010 年, 東北 大学大学院教育情報学研究部講師. 博士 (工学) 。聴覚 障害者支援技術，および手話コミュニケーション支援に 関する研究に従事. 正会員.

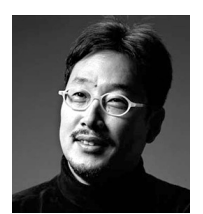

渡部信一 1983 年, 東北大学大学院教育学研究 科博士課程前期修了。国立療養所宮城病院 (現 : 国立病 院機構宮城病院）心理言語療法士，福岡教育大学助教授, 東北大学大学院教育学研究科助教授などを経て, 2002 年, 東北大学大学院教育情報学研究部教授. 博士 (教育学). 専門は「学び」の認知科学. 